\title{
A major T-cell-inducing cytosolic 23 kDa protein antigen of the vaccine candidate Mycobacterium habana is superoxide dismutase
}

\author{
Deepa Bisht, ${ }^{1} \dagger$ Jyoti Mehrotra, ${ }^{1}$ M. S. Dhindsa, ${ }^{2}$ N. B. Singh ${ }^{3}$ \\ and Sudhir Sinha ${ }^{1}$
}

Author for correspondence: Sudhir Sinha. Tel: +91522 212411 ext. 4282. Fax: +91522 223405.

1,3 Divisions of Membrane
Biology' and
Microbiology3, Central
Drug Research Institute,
PO Box 173, Lucknow-
226001, India
2 Skin Centre, Base
Hospital, Lucknow, India Hospital, Lucknow, India

\begin{abstract}
This study describes the purification and immunochemical characterization of a major 23 kDa cytosolic protein antigen of the vaccine candidate

Mycobacterium habana (TMC 5135). The $23 \mathrm{kDa}$ protein alone was salted out from the cytosol at an ammonium sulfate saturation of 80-95\%. It represented about $1.5 \%$ of the total cytosolic protein, appeared glycosylated by staining with periodic acid/Schiff's reagent, and showed a pl of approximately 5.3. Its native molecular mass was determined as approximately $48 \mathrm{kDa}$, suggesting a homodimeric configuration. Immunoblotting with the WHO-IMMLEP/IMMTUB mAbs mc5041 and IT61 and activity staining after native PAGE established its identity as a mycobacterial superoxide dismutase (SOD) of the Fe/Mn type. The sequence of the $18 \mathrm{~N}$-terminal amino acids, which also contained the binding site for mc5041, showed a close resemblance, not only with the reported deduced sequences of Mycobacterium leprae and Mycobacterium tuberculosis Fe/MnSODs, but also with human MnSOD. In order to study its immunopathological relevance, the protein was subjected to in vivo and in vitro assays for $\mathrm{T}$ cell activation. It induced, in a dose-related manner, skin delayed hypersensitivity in guinea-pigs and lymphocyte proliferation in BALB/c mice primed with $M$. habana. Most significantly, it also induced lymphocyte proliferative responses, in a manner analogous to $M$. leprae, in human subjects comprising tuberculoid leprosy patients and healthy contacts.
\end{abstract}

Keywords: vaccine, Mycobacterium babana, $23 \mathrm{kDa}$ protein, superoxide dismutase, $\mathrm{T}$ cell response

\section{INTRODUCTION}

A formidable worldwide resurgence of tuberculosis is being witnessed in the wake of AIDS (Weiss, 1992), and leprosy, although on the decline, persists as a major public health problem in developing countries (WHO, 1988). Dismal performances of BCG in some populations, as well as of other candidate integral vaccines undergoing human trials (Fine \& Rodriguez, 1990; Convit et al.,

† Present address: Institute of Microbial Technology, Chandigarh, India. Abbreviations: $\mathrm{DH}$, delayed hypersensitivity; IEF, isoelectric focusing; PAS reagent, periodic acid/Schiff's reagent; PHA, phytohaemagglutinin; SOD, superoxide dismutase.

The EMBL accession number for the sequence reported in this paper is P80582.
1992), have underlined the need for molecular characterization of immunopathologically important mycobacterial constituents in the quest for better drugs, diagnostic techniques and vaccines. Attention has primarily been focused on proteins, with a growing realization that the T-cell-mediated immune responses generated by them (Germain, 1994) could be of a diagnostic or prophylactic value. In addition, proteins working as vital enzymes or virulence factors for the microbe could serve as suitable targets for new drug development. Thus, an array of antigenic and/or enzymic proteins has been isolated and characterized from various compartments of a mycobacterial cell, viz. the cytosol, cell membrane and cell wall, and from the growth medium (Young et al., 1992). A good number of these proteins, particularly the cytosolic ones, have also been genetically cloned, and studies addressing the vaccine or diagnostic potential of 
some of them are well underway (Young \& Cole, 1993; Gelber et al., 1994).

Mycobacterium habana (TMC 5135, Mycobacterium simiae serovar 1) has shown promising results as a candidate vaccine against leprosy and tuberculosis in the mouse model in studies conducted at our laboratory (Gupta et al., 1979) and elsewhere (Singh et al., 1989). It could also prime monkeys for the lepromin skin test (Singh et al., 1992). Further, this cultivable mycobacterial strain was found to share some of the antigens with Mycobacterium leprae, including a specific determinant on an $18 \mathrm{kDa}$ heatshock protein (Lamb et al., 1990). We report here the isolation and immunochemical characterization of a prominent $23 \mathrm{kDa}$ cytosolic protein of $M$. babana, whose real identity, in the course of the study, was established as a superoxide dismutase (SOD) bearing structural and antigenic homologies with $\mathrm{Fe} / \mathrm{MnSODs}$ of Mycobacterium tuberculosis and $M$. leprae. The immunological importance of the purified protein was assessed by the parameters for $T$ cell activation, viz. skin delayed hypersensitivity $(\mathrm{DH})$ in guinea-pigs and lymphocyte proliferation assays in mice as well as in human subjects comprising leprosy patients and healthy contacts.

\section{METHODS}

Human subjects. Fourteen individuals were selected for this study. Eleven of them were patients of tuberculoid or borderline tuberculoid leprosy, classified according to the clinico-bacteriological and immunohistological criteria of Ridley \& Jopling (1966). They were admitted to the wards of the Skin Centre, Base Hospital, Lucknow, India, and were receiving multi-drug treatment (WHO, 1988) for periods ranging from 1 to 10 months. The remaining three subjects were healthy laboratory workers environmentally exposed to mycobacterial antigens (healthy contacts). Informed consent was obtained from all subjects prior to drawing a $10 \mathrm{ml}$ sample of venous blood.

Protein purification. $M$. babana (TMC 5135) was cultured in Sauton's liquid medium at $37{ }^{\circ} \mathrm{C}$ on an orbital shaker. Cells were harvested in late-exponential phase ( 3 weeks) and subjected to the recommended protocol for subcellular fractionation (Brodie et al., 1979). Briefly, batches of bacterial cells $(5 \mathrm{~g}$ wet wt per batch) were washed and suspended $\left(0.2 \mathrm{~g} \mathrm{ml}^{-1}\right)$ in sonication buffer $(50 \mathrm{mM}$ Tris $/ \mathrm{HCl}, \mathrm{pH} 7 \cdot 4$, with $10 \mathrm{mM} \mathrm{MgCl}, 1 \mathrm{mM}$ PMSF and $1 \mathrm{mM}$ EGTA) and sonicated for a total of $10 \mathrm{~min}$ using $50 \%$ output $(100 \%=475 \mathrm{~W})$ and $50 \%$ duty cycle (on/off) of a sonicator (Heat Systems Ultrasonics). The sonicate was centrifuged at $23000 \mathrm{~g}$ for $30 \mathrm{~min}$ to remove the broken cell walls and the supernatant was recentrifuged at $150000 \mathrm{~g}$ for $90 \mathrm{~min}$ to remove the membrane fragments and recover the cytosol. Protein estimations were done by a modified Lowry method (Markwell et al., 1978).

The major $23 \mathrm{kDa}$ cytosolic protein of $M$. babana, as visualized by SDS-PAGE (described below), could be purified to homogeneity by a temperature-controlled fractional salt precipitation procedure (Scopes, 1987). Initially, cytosol (about $3 \mathrm{mg}$ protein $\mathrm{ml}^{-1}, 30 \mathrm{ml}$ per batch) was subjected to serial precipitations at $20 \%, 40 \%, 60 \%, 80 \%$ and $95 \%$ ammonium sulfate (enzyme grade, Sigma) saturation. The precipitates were collected by centrifugation, dissolved and dialysed against PBS $(10 \mathrm{mM}$ sodium phosphate, $150 \mathrm{mM} \mathrm{NaCl} ; \mathrm{pH} 7 \cdot 4)$, and sub- jected to SDS-PAGE. After observing that the $23 \mathrm{kDa}$ protein was almost exclusively precipitated between $80 \%$ and $95 \%$ salt saturation, the procedure was simplified as follows. All other cytosolic proteins were precipitated in the first step by applying $80 \%$ salt saturation, then, in the second step, saturation of the supernatant was raised to $95 \%$ to precipitate the $23 \mathrm{kDa}$ protein. In the majority of the batches (six out of eight), the isolated protein exhibited single band purity by both Coomassie blue and silver staining after SDS-PAGE. Minor contaminants in occasional batches could easily be removed by applying a second cycle of salt precipitation to the sample after making it free from ammonium sulfate by extensive dialysis against PBS. Homogeneity of various batches of isolated protein was also confirmed by isoelectric focusing (IEF), using the method described below.

SDSPAGE and specific staining. SDS-PAGE under reducing conditions was done by the method of Laemmli (1970), using a $12.5 \%(\mathrm{w} / \mathrm{v})$ resolving gel in a mini slab-gel apparatus (Broviga). Molecular mass markers were obtained from Sigma. After electrophoresis, gels were stained for proteins with either Coomassie blue or a silver stain (Wray et al., 1981). Staining was also done with periodic acid/Schiffs (PAS) reagent in order to visualize glycosylation (Leach et al., 1980).

IEF. This was done according to the procedure described by Dunbar et al. (1990) in cylindrical gels (4 mm diameter) using ampholytes purchased from Pharmacia. The upper, cathode buffer was $0.02 \mathrm{M} \mathrm{NaOH}$ and $0.085 \%$ phosphoric acid was used as the lower, anode buffer. After prefocusing the ampholytes $(250 \mathrm{~V}$ for $2 \mathrm{~h}$ ), IEF of a 5-10 $\mu \mathrm{g}$ protein sample was carried out at $1000 \mathrm{~V}$ for $6 \mathrm{~h}$. The gels were fixed and stained with Coomassie blue. pI values of standard markers (Sigma) were plotted against the respective migration distances and the $\mathrm{pI}$ of purified protein was extrapolated from this curve.

Determination of native molecular mass. The native protein molecular mass marker kit of Sigma was used and supplier's instructions ('Technical Bulletin no. MKR-137) were followed. Briefly, purified protein and markers were electrophoresed on a set of cylindrical gels with different polyacrylamide concentrations $(7 \%, 9 \%, 10 \%$ and $12 \%, \mathrm{w} / \mathrm{v})$. For each protein, $100 \log \left(R_{F} \times 100\right)$ was plotted against the percentage gel concentration and individual slopes ( = retardation coefficient) were determined. Afterwards, log (negative) slope was plotted against log molecular mass for each marker and from this linear plot, the molecular mass of purified protein was extrapolated.

N-terminal amino acid sequence analysis. The protocol of Matsudaira (1987) was followed. The purified protein was electroblotted on a PVDF membrane (Immobilon-P, $0.45 \mu \mathrm{m}$; Sigma) using CAPS buffer. The blotted protein was visualized by Coomassie blue staining and the corresponding membrane area was excised, washed, dried and used for $\mathrm{N}$-terminal sequencing. The sequencing was done using the model $470 \mathrm{~A}$ Gas Phase Sequenator (Applied Biosystems) at the DBT facility, Indian Institute of Science, Bangalore, India (courtesy of Professor N. Appaji Rao).

Anti-SOD antibodies and immunoblotting. A panel of mAbs, including those that react with two distinct but shared epitopes of mycobacterial SOD, mc5041 (SA1D2D) and IT61 (F116-5) (Khanolkar-Young et al., 1992), was provided by IMMLEP/ IMMTUB Monoclonal Antibody Bank of WHO (courtesy of Dr T. M. Shinnick). A monospecific polyclonal antibody against purified the $23 \mathrm{kDa}$ protein of $M$. babana was raised by immunizing (intradermal, multiple sites) a rabbit with the protein emulsified in Freund's incomplete adjuvant. Optimal titres were attained after the third biweekly booster. 
For immunoblotting, antigens resolved by SDS-PAGE were electrophoretically blotted (Towbin et al., 1979) on nitrocellulose paper $(0.45 \mu \mathrm{m}$ pore size; Sigma) using a Trans-Blot apparatus (Bio-Rad). Later, individual strips cut out from paper were probed with anti-SOD antibodies. Briefly, strips were blocked ( $2 \mathrm{~h}$ at room temperature) with $3 \%(\mathrm{w} / \mathrm{v})$ skimmed milk powder (Anikspray, Lipton) and incubated $(2 \mathrm{~h}$, room temperature) with appropriate dilutions of anti-SOD antibodies (1:50 for IT61, $1: 500$ for mc5041 and 1:500 for rabbit antiserum) prepared in $1 \%$ milk. The washed strips were reincubated ( $2 \mathrm{~h}$, room temperature) with $1: 1000$ dilutions (in $1 \%$ milk) of affinity-purified, peroxidase-conjugated anti-mouse or anti-rabbit immunoglobulins (Sigma). After final washings, the colour was developed with 4-chloronaphthol (Sigma) as substrate.

Activity staining in a gel. The purified protein as well as the cytosol of $M$. babana were subjected to non-denaturing (native) slab-gel PAGE in a $12.5 \%$ gel using the buffer system of Laemmli (1970), omitting SDS and reducing agent. SOD activity was visualized by negative staining with nitro blue tetrazolium (NBT) (Beauchamp \& Fridovich, 1971). Briefly, gels were soaked in a solution of $0.2 \% \mathrm{NBT}, 0.025 \mathrm{M}$ $N, N, N^{\prime}, N^{\prime}$,-tetramethylethylenediamine and $2 \cdot 8 \times 10^{5} \mathrm{M}$ riboflavin in potassium phosphate buffer $(50 \mathrm{mM}, \mathrm{pH} 7 \cdot 8)$ for $30 \mathrm{~min}$ at room temperature and later illuminated with fluorescent light until colourless zones indicating SOD activity were visible against a uniformly blue background. For the determination of the metal cofactor by the enzyme inhibition method (Takao $e t$ al., 1991), gel strips, after native PAGE, were incubated at room temperature for $30 \mathrm{~min}$ with $10 \mathrm{mM}$ potassium cyanide or $10 \mathrm{mM}$ sodium azide or for $1 \mathrm{~h}$ with $0.5 \mathrm{mM}$ hydrogen peroxide. The control strip was incubated with phosphate buffer alone. SOD activity was stained by the NBT method.

DH tests in guinea-pigs. A previously described protocol (Sinha et al., 1987) was followed. Guinea-pigs were primed with an autoclaved saline suspension of $M$. babana by administering two intradermal injections $(0.1 \mathrm{ml}$ each) in the groin region ( $3 \mathrm{mg}$ wet bacterial wt per animal). After 4 weeks, the animals were tested (in groups of three) for skin $\mathrm{DH}$ with indicated doses of antigens (in $0.1 \mathrm{ml}$ saline). The mean diameter of the erythematous reaction was recorded at specified time intervals. A group of unimmunized animals served as a negative control.

T cell proliferation assays in mice. BALB/c mice were primed by intradermal injections (on both flanks) of an autoclaved saline suspension of $M$. babana $(1.5 \mathrm{mg}$ wet bacterial wt per mouse). After 3-4 weeks, the animals were sacrificed by cervical dislocation. The spleen was removed and mashed gently in culture medium (RPMI 1640, Sigma) over a fine stainless-steel wire mesh using the glass piston of a syringe. The single-cell suspension thus obtained was sedimented by centrifugation $(400 \mathrm{~g}$ for $10 \mathrm{~min})$ and treated with lysis buffer $\left(0 \cdot 14 \mathrm{M} \mathrm{NH}_{4} \mathrm{Cl}\right.$, $0.017 \mathrm{M}$ Tris $/ \mathrm{HCl}, \mathrm{pH} .4$ ) to lyse the erythrocytes. The remaining cells were washed and suspended in medium containing $5 \%(\mathrm{v} / \mathrm{v})$ foetal calf serum (FCS, Biological Industries), and then passed through a column of nylon wool (BioTest AG) for the enrichment of T cells (Julius et al., 1973). Cells in the eluate were washed, adjusted to $2 \times 10^{6} \mathrm{cells} \mathrm{ml}^{-1}$, and dispensed $(0.1 \mathrm{ml}$ per well) into 96 -well flat-bottomed tissue culture plates (Corning). Cultures were set in triplicate, with or without the indicated doses (in $10 \mu \mathrm{l}$ ) of antigen or mitogen, in medium supplemented with $10 \%$ heat-inactivated FCS and $10^{-5} \mathrm{M} \mathrm{2-}$ mercaptoethanol (total culture volume $=0.2 \mathrm{ml}$ per well). Incubations were done for $4 \mathrm{~d}$ in a $\mathrm{CO}_{2}$ incubator, and $18 \mathrm{~h}$ prior to termination, the cultures were pulsed with $1 \mu \mathrm{Ci}$ $(37 \mathrm{kBq})\left[{ }^{3} \mathrm{H}\right]$ thymidine [methyl-T, specific activity approx.
$20 \mathrm{Ci} \mathrm{mmol}^{-1}$ (740 GBq); from BARC, Bombay, India] per well. Cells were harvested on a cell harvester and the radioactivity was measured in a liquid scintillation counter.

Human T cell proliferation assays. Mononuclear cells were isolated from heparinized blood by density gradient centrifugation over Ficoll-isopaque (Boyum, 1968). The washed cells were counted, adjusted to $2 \times 10^{6}$ cells ml $\mathrm{ml}^{-1}$ in culture medium (RPMI 1640), and dispensed ( $0.1 \mathrm{ml}$ per well) into 96-well flatbottomed culture plates. Cultures were set in triplicate, with or without the indicated concentrations of antigen or mitogen, in culture medium supplemented with $10 \%$ heat-inactivated pooled normal human serum (total volume $=0.2 \mathrm{ml}$ per well) and incubated for $6 \mathrm{~d}$ in a $\mathrm{CO}_{2}$ incubator. The cultures were pulsed with [ $\left.{ }^{3} \mathrm{H}\right]$ thymidine $[1 \mu \mathrm{Ci}(37 \mathrm{kBq})$ per well] $18 \mathrm{~h}$ before harvesting, and the radioactivity of the harvested cells was measured in a liquid scintillation counter.

\section{RESULTS}

\section{Homogeneity and yield of purified protein}

SDS-PAGE of the $M$. babana cytosol under reducing conditions revealed the presence of a prominent $23 \mathrm{kDa}$ protein. Its abundance is evident from Fig. 1(a), which shows protein profiles of serially diluted cytosol. By PAS staining, the $23 \mathrm{kDa}$ protein appeared to be glycosylated, like the majority of the other proteins (Fig. 1b). All (a)

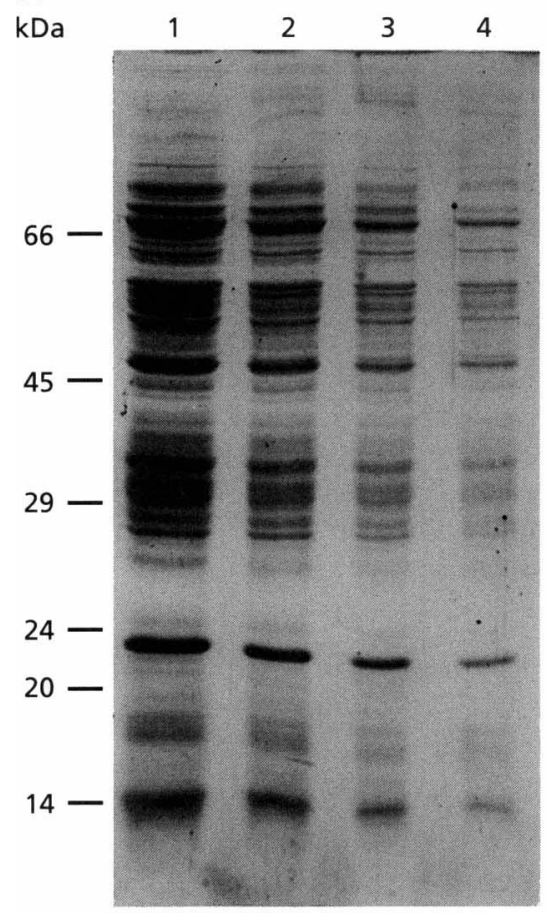

(b)

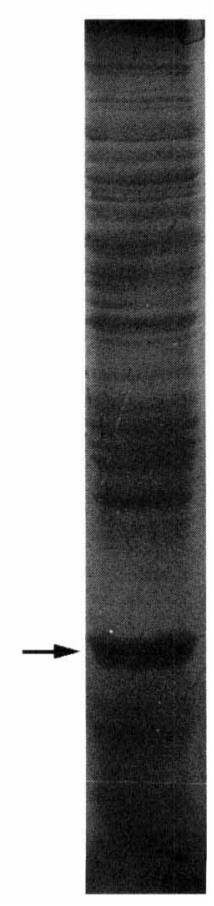

Fig. 1. (a) SDS-PAGE of serial twofold dilutions of $M$. habana cytosol showing the abundance of the $23 \mathrm{kDa}$ protein. Lanes: 1 , $30 \mu \mathrm{g}$ cytosolic protein; $2,15 \mu \mathrm{g}$ protein; $3,7.5 \mu \mathrm{g}$ protein; 4 , $3.75 \mu \mathrm{g}$ protein. (b) SDS-PAGE and PAS staining of cytosolic proteins showing glycosylation of the $23 \mathrm{kDa}$ protein (arrow) and other proteins. 
(a)

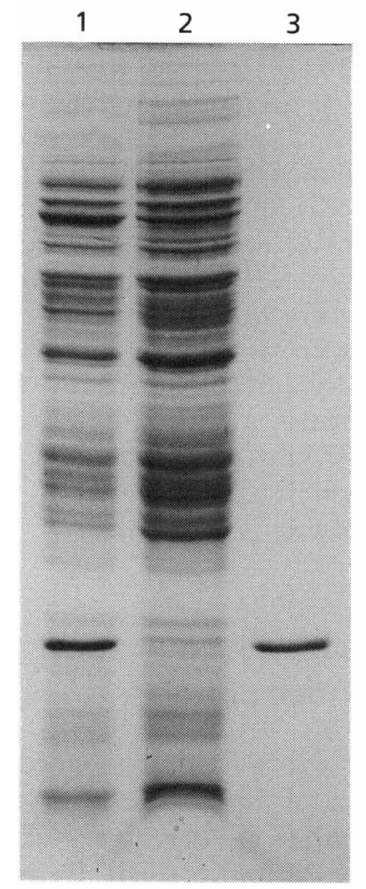

(b)

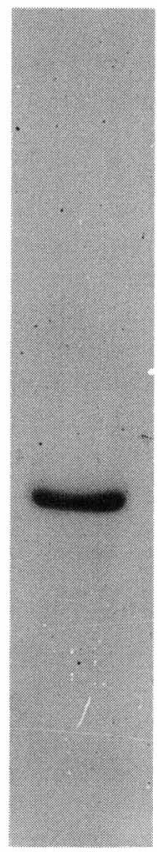

(a)

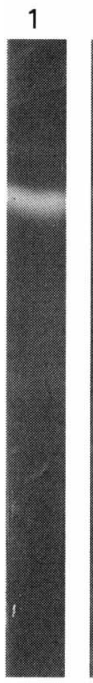

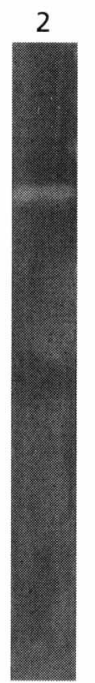
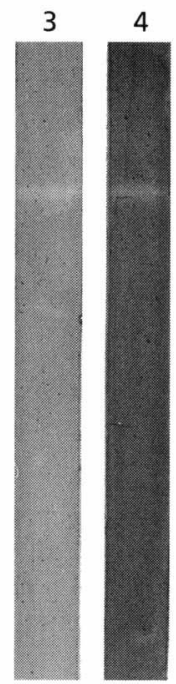

(b)

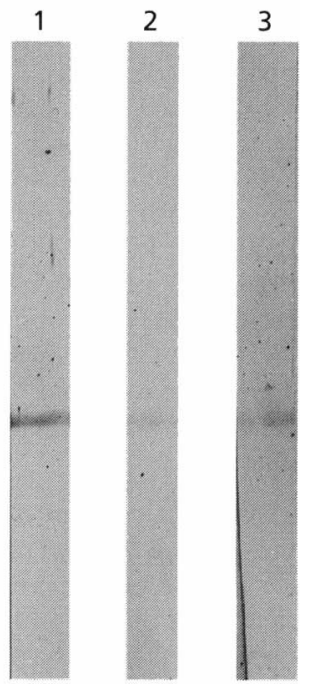

Fig. 3. (a) Characterization of the isolated protein as SOD by activity staining after native gel electrophoresis. Lanes: 1, cytosol; 2, isolated protein. Enzyme activity was not inhibited by $\mathrm{KCN}$ (lane 3), $\mathrm{NaN}_{3}$ (lane 4) or $\mathrm{H}_{2} \mathrm{O}_{2}$ (lane 5), indicating the presence of Fe/Mn as the metal cofactor. (b) Sharing of $\mathrm{B}$ cell epitopes with other mycobacterial SODs seen by immunoblotting using rabbit anti- $M$. habana SOD antiserum (lane 1) and mAbs IT61 (lane 2) and mc5041 (lane 3).

F. 2. (a) Purification of the $23 \mathrm{kDa}$ protein monitored by SDS PAGE and Coomassie blue staining. Lanes: 1, cytosol; 2, cytosolic protein precipitated at $80 \%$ salt saturation; $3,23 \mathrm{kDa}$ protein precipitated at $80-95 \%$ salt saturation. (b) Purity of the isolated protein indicated by silver staining.

cytosolic proteins, except the $23 \mathrm{kDa}$ protein, were precipitated at $80 \%$ saturation with ammonium sulfate, whereas the $23 \mathrm{kDa}$ protein alone was precipitated between 80 and $95 \%$ saturation (Fig. 2a). Precision in salt saturation as a function of temperature was found to be a critical requirement for this purification process. SDSPAGE and silver staining served as the first criterion for homogeneity of the purified protein (Fig. 2b). The second criterion was IEF, in which the protein was focused as a single band at a $\mathrm{pI}$ of about $5 \cdot 3$. Its amenability to $\mathrm{N}$ terminal sequence analysis (described below) was also evidence of homogeneity. The native molecular mass of purified protein was determined to be approximately $48 \mathrm{kDa}$, indicating its natural presence as a homodimer.

One gram wet bacterial weight yielded about $20 \mathrm{mg}$ cytosolic protein, from which about $0.3 \mathrm{mg} 23 \mathrm{kDa}$ protein could be isolated (mean of five batches). Thus the isolated protein constituted approximately $1.5 \%$ of the total cytosolic protein.

\section{Characterization of the protein as SOD}

Initially, in view of the similarity in molecular masses, immunoblotting of purified protein was attempted with IMMLEP/IMMTUB mAb IT61 (F116-5). This antibody is known to react with a common epitope of the $23 \mathrm{kDa}$ mycobacterial antigen, identified later as SOD. After

observing a positive reaction, another $\mathrm{mAb}$, mc5041 (SA1D2D), against $M$. leprae SOD, described earlier as a $28 \mathrm{kDa}$ antigen (Young et al., 1985), was used which also produced a positive reaction. Results of immunoblotting with both the $\mathrm{mAbs}$ and a rabbit antiserum raised against the purified $23 \mathrm{kDa} M$. babana protein are shown in Fig. 3(b).

Further characterization of the enzyme was done by activity staining in a native gel in the presence or absence of cofactor-specific inhibitors. Sensitivity to cyanide denotes $\mathrm{Cu}, \mathrm{ZnSOD}$ whereas $\mathrm{Fe} / \mathrm{MnSODs}$ are only partially inhibited by azide or hydrogen peroxide and not at all by cyanide. As seen in Fig. 3(a), the presence of SOD activity was evident in the cytosol as well as in purified protein. None of the inhibitors abrogated this activity, indicating the probability of the enzyme being of the $\mathrm{Fe} / \mathrm{Mn}$ type.

\section{Structural identity with related SODs}

The $\mathrm{N}$-terminal sequence of the purified protein, up to 18 amino acid residues, was determined as follows: ${ }^{1} \mathrm{Ala}-$ Glu-Tyr-Thr-Leu-Pro-Asp-Leu-Gly-Trp-Asp-Tyr-AlaAla-Ser-Gly-Pro-Gly ${ }^{18}$. A comparison of this partial sequence was made with that of other SODs reported in the literature. A striking resemblance of $M$. babana SOD was observed with $\mathrm{Fe} / \mathrm{MnSODs}$ of $M$. tuberculosis (Zhang et al., 1991), M. leprae (Thangaraj et al., 1989) and man (Barra et al., 1984), whereas there was no such homology 
M. habana Fe/Mn, native:

M. leprae

Mn, deduced:

M. tuberculosis, $\mathrm{H}_{37} \mathrm{Ra}$

Fe/Mn, deduced:

Human

Mn, native:

Human

Cu, Zn, native:

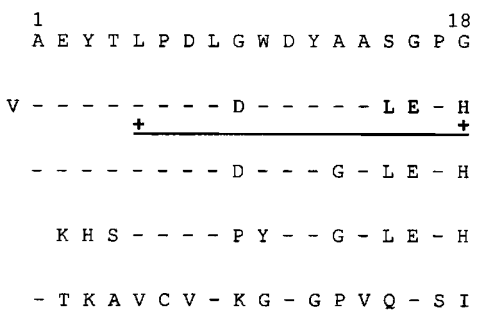

Fig. 4. A comparison of the $\mathrm{N}$-terminal sequence of $M$. habana SOD with that of $M$. leprae MnSOD (Thangaraj et al., 1989), $M$. tuberculosis Fe/MnSOD (Zhang et al., 1991), human MnSOD (Barra et al., 1984) and human Cu,ZnSOD (Jabusch et al., 1980). Blanks $(-)$ indicate amino acid residues identical to $M$. habana SOD at the corresponding positions; $+\ldots++$ indicates the mapped epitope for anti-SOD mAb mc5041 (SA1D2D) in the case of $M$. leprae (Thangaraj et al., 1990).

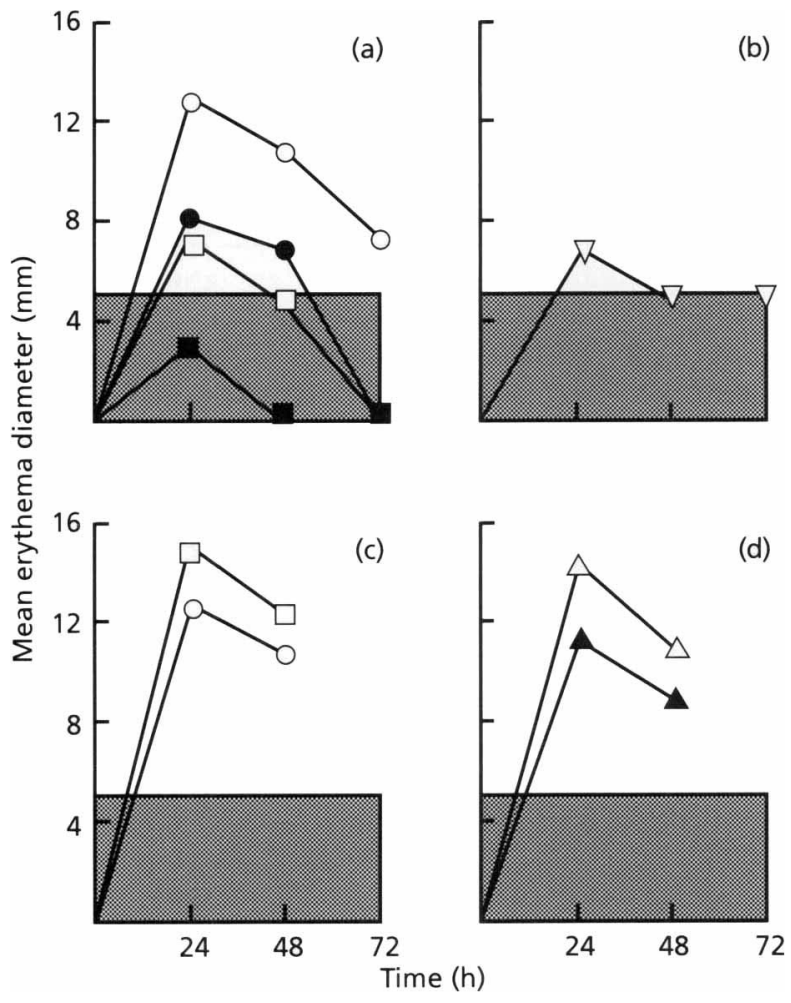

Fig. 5. DH responses to $M$. habana cytosol and purified protein (SOD) in guinea-pigs. All reactions peaked at $24 \mathrm{~h}$ and those of $<5 \mathrm{~mm}$ (shaded area) were considered negative. (a) Dose response with cytosol tested at $2.5(0), 1.25(0), 0.625(\square)$ and $0.312(\square) \mu \mathrm{g}$ protein. (b) Dose response with SOD tested at $2.5 \mu \mathrm{g}$ protein $(\nabla)$ and its twofold dilutions, which did not produce any reaction (values correspond to baseline). (c) $\mathrm{DH}$ with $5(\square)$ and $2.5(O) \mu \mathrm{g}$ cytosolic protein. Equivalent reactions were produced by $10(\Delta)$ and $5(\Delta) \mu \mathrm{g}$ SOD (d).

with human Cu,ZnSOD (Jabusch et al., 1980) (Fig. 4). This confirmed the findings about the metal cofactor of $M$. babana SOD based on enzyme inhibition studies. This comparison also explained the reactivity of $\mathrm{mAb}$ SA1D2D with $M$. babana SOD, since the corresponding epitope has been mapped to the $\mathrm{N}$-terminus of $M$. leprae SOD (Thangaraj et al., 1990), as indicated in Fig. 4.

\section{DH response in guinea-pigs}

Initially, a dose response was determined using serial twofold dilutions of cytosol or purified protein, beginning at $2.5 \mu \mathrm{g}$ (Fig. 5). The mean diameter of erythema was recorded at the specified time intervals. The positive reactions peaked at $24 \mathrm{~h}$. At least $0.625 \mu \mathrm{g}$ cytosolic protein was needed to elicit a positive reaction (Fig. 5a), whereas the corresponding value for purified protein was $2.5 \mu \mathrm{g}$ (Fig. 5b). In the second experiment, guinea-pig DH responses to the selected doses of cytosol and SOD were evaluated. Comparable reactions were seen when the tested dose of SOD was twice that of the cytosol (Fig. $5 c$, d). Unimmunized guinea-pigs did not react with any of the antigen doses.

\section{Murine T cell proliferation}

Lymphocyte proliferative responses of $B A L B / c$ mice to phytohaemagglutinin (PHA, a T cell mitogen), M. babana cytosol and $23 \mathrm{kDa}$ protein (SOD) are shown in Table 1. Optimal doses, as indicated in the Table, were determined on the basis of pilot experiments. The mean response to SOD alone was about $25 \%$ of that obtained with whole cytosol.

\section{Human T cell proliferation}

In order to evaluate the human-T-cell-activating potential of the purified protein, the $\mathrm{T}$ cell donors were selected from those individuals who are generally regarded as 'responders' for mycobacterial antigens, viz. tuberculoid leprosy patients and healthy contacts (Ridley \& Jopling, 1966; Young et al., 1992).

$\mathrm{T}$ cell proliferative responses (Table 2) were recorded with predetermined optimal doses of PHA (serving as positive control), $M$. leprae cytosol, $M$. babana cytosol and the $23 \mathrm{kDa}$ protein (SOD). On the basis of their response to $M$. leprae cytosol, the donors were arbitrarily categorized as 'high responders' ( $\Delta$ c.p.m. $>10000$ ) or 'low responders' $(\Delta$ c.p.m. $<2000)$. Accordingly, six out of eight high responders for $M$. leprae cytosol also turned out to be high responders for SOD $(\Delta$ c.p.m. $=16332-46820$ ) and all six low responders showed low responses to SOD as well $(\Delta$ c.p.m. $=14-888)$. The proliferative responses to $M$. babana cytosol, on the other hand, did not follow this pattern so closely. Four out of six low responders for $M$. leprae cytosol showed a medium to high response for $M$. babana cytosol (Ac.p.m. $=8967-51509$ ).

\section{DISCUSSION}

The family of SODs (EC 1.15.1.1) normally functions to protect cells from toxic effects of superoxide anions $\left(\mathrm{O}_{2}^{-}\right)$, generated during various metabolic processes, by catalysing their dismutation to hydrogen peroxide and 
Table 1. Murine lymphocyte proliferative responses

The optimal doses of PHA, M. babana cytosol and SOD per $10^{6}$ cells were worked out separately. The values are the mean $\Delta$ c.p.m. [= c.p.m.(antigen/mitogen - medium)]. The SEM of triplicate cultures was $<15 \%$ of the mean.

\begin{tabular}{|c|c|c|c|c|}
\hline \multirow[t]{2}{*}{ Animal no. } & \multicolumn{2}{|c|}{ Controls } & \multicolumn{2}{|c|}{ Antigens } \\
\hline & Medium only & $\begin{array}{c}\text { PHA } \\
\left(10 \mu \mathrm{g} \mathrm{ml}^{-1}\right)\end{array}$ & $\begin{array}{l}\text { M. habana cytosol } \\
\left(25 \mu \mathrm{g} \mathrm{ml}^{-1}\right.\end{array}$ & $\begin{array}{c}\text { SOD } \\
\left(12.5 \mu \mathrm{g} \mathrm{ml}^{-1}\right)\end{array}$ \\
\hline 1 & 4805 & 66289 & 11460 & 4420 \\
\hline 2 & 2419 & 77364 & 10060 & 1755 \\
\hline 3 & 1716 & 60317 & 6569 & 3264 \\
\hline 4 & 4950 & 46425 & 20297 & 4037 \\
\hline \multirow[t]{2}{*}{5} & 3222 & 53915 & 13699 & 1659 \\
\hline & & $60862 \pm 5286^{*}$ & $12417 \pm 2285^{*}$ & $3027 \pm 570^{*}$ \\
\hline
\end{tabular}

*Mean士 SEM.

Table 2. Human lymphocyte proliferative responses

The optimal doses of PHA, M. leprae cytosol, M. babana cytosol and SOD per $10^{6}$ cells were worked out separately. The values are the mean $\Delta$ c.p.m. [ = c.p.m.(antigen/mitogen - medium)]. The SEM of triplicate cultures was $<15 \%$ of the mean.

\begin{tabular}{|c|c|c|c|c|c|}
\hline \multirow[t]{2}{*}{ Patient no./type* } & \multicolumn{2}{|c|}{ Controls } & \multicolumn{3}{|c|}{ Antigens } \\
\hline & Medium only & $\begin{array}{c}\text { PHA } \\
\left(2 \mu \mathrm{g} \mathrm{ml}^{-1}\right)\end{array}$ & $\begin{array}{l}\text { M. leprae cytosol } \\
\left(25 \mu \mathrm{g} \mathrm{ml}^{-1}\right)\end{array}$ & $\begin{array}{l}\text { M. habana cytosol } \\
\left(25 \mu \mathrm{g} \mathrm{ml}^{-1}\right)\end{array}$ & $\begin{array}{c}\text { SOD } \\
\left(12.5 \mu \mathrm{g} \mathrm{ml}^{-1}\right)\end{array}$ \\
\hline \multicolumn{6}{|l|}{ High responders } \\
\hline $1 / \mathrm{TT}$ & 670 & 72068 & 16408 & 22874 & 16332 \\
\hline $2 / \mathrm{BT}$ & 2338 & 28638 & 14564 & 54090 & 18647 \\
\hline $3 / \mathrm{TT}$ & 625 & 58711 & 66707 & 162146 & 46820 \\
\hline $4 / \mathrm{BT}$ & 3937 & 22819 & 63686 & 143771 & 26979 \\
\hline $5 / \mathrm{BT}$ & 2002 & 106590 & 18427 & 15766 & 19598 \\
\hline $6 / \mathrm{HC}$ & 521 & 115615 & 37086 & 50514 & 23633 \\
\hline $7 / \mathrm{BT}$ & 443 & 133405 & 12115 & 45662 & 862 \\
\hline $8 / \mathrm{HC}$ & 590 & 165251 & 12499 & 112740 & 297 \\
\hline \multicolumn{6}{|l|}{ Low responders } \\
\hline $9 / \mathrm{HC}$ & 754 & 116745 & 1784 & 21247 & 14 \\
\hline $10 / \mathrm{BT}$ & 1846 & 94022 & 287 & 51509 & 180 \\
\hline $11 / \mathrm{TT}$ & 321 & 98026 & 408 & 11161 & 122 \\
\hline $12 / \mathrm{TT}$ & 497 & 125744 & 888 & 8967 & 888 \\
\hline 13/BT & 500 & 123532 & 34 & 2100 & 617 \\
\hline $14 / \mathrm{TT}$ & 310 & 250530 & 228 & 1457 & 173 \\
\hline
\end{tabular}

*'TT, Tuberculoid leprosy; BT, borderline tuberculoid leprosy; HC, healthy contact.

molecular oxygen (Fridovich, 1986). The importance of $\mathrm{O}_{2}^{-}$has been accentuated by the fact that it may combine with nitric oxide (NO), another potent cytotoxic molecule, to transiently produce peroxynitrite $\left(\mathrm{ONOO}^{-}\right)$, which could be more lethal than either of the reactants (Radi et al., 1991). Since $\mathrm{O}_{2}^{-}$and $\mathrm{NO}$ are also primary reaction products of a 'respiratory burst', the major microbicidal mechanism of an activated phagocyte, SODs of various pathogens have been viewed as virulence factors (Beaman \& Beaman, 1984). This understanding has triggered a series of studies pertaining to structure function analysis of SODs from various parasites as well as their hosts. Some biochemical properties of $M$. leprae and $M$. tuberculosis SODs were initially reported by Kusunose et al. (1976, 1981) and Wheeler \& Gregory (1980). The genes for both SODs have been cloned and sequenced (Thangaraj et al., 1989, 1990; Zhang et al., 1991) and some B cell epitopes on these proteins have been identified with the help of mAbs (Young et al., 1985; Khanolkar-Young et al., 1992). Very recently, crystal- 
lization and three-dimensional structure determination of the recombinant $M$. tuberculosis $\left(\mathrm{H}_{37} \mathrm{Ra}\right) \mathrm{SOD}$ has been reported (Cooper et al., 1995).

It was not immediately obvious that the prominent $23 \mathrm{kDa}$ cytosolic protein of $M$. habana was, in fact, SOD. Activity staining in denaturing gels was not attempted since it was highly unlikely for an enzyme to retain its activity under such conditions. Secondly, considerable uncertainty existed about the molecular mass of a mycobacterial SOD. Its subunit size has been reported as $28 \mathrm{kDa}$ for $M$. leprae (Young et al., 1985) and $21 \mathrm{kDa}$ for M. tuberculosis (Kusunose et al., 1976). On the other hand, the subunit size of both the SODs as deduced from respective DNA sequences has been found to be $23 \mathrm{kDa}$. Uncertainty also prevails regarding the native molecular configuration of SODs, which in the case of $M$. babana appeared to be homodimeric. Native SODs from various microbial sources have been found to exist in configurations ranging from monomeric (Spiegelhalder et al., 1993) to tetrameric. $M$. tuberculosis SOD exists as a homotetramer of $88 \mathrm{kDa}$ (Kusunose et al., 1976) and the native molecular mass of $M$. leprae SOD has been reported as $40 \mathrm{kDa}$ (? dimer) (Kusunose et al., 1981). Thirdly, despite the lack of signal peptide sequence (Zhang et al., 1991), mycobacterial and other SODs have been regarded as predominantly secretory molecules (Kusunose et al., 1976; Cooper et al., 1995), whereas in the case of $M$. babana, its secretory level was below the detection limits (data not shown). Nonetheless, in some avirulent mycobacteria, the enzyme has been found to remain intracellular (Kusunose et al., 1976).

The $M$. babana protein could be isolated from the cytosol solely by means of a 'salting out' procedure. It is well documented that SODs from various sources get precipitated at a relatively higher ammonium sulfate saturation, between 62.5 and $95 \%$ (Kusunose et al., 1976; Beaman et al., 1982; Takao et al., 1991). However, purification to homogeneity has invariably involved additional steps; typically, a passage through anion-exchange and gelfiltration columns. In the case of $M$. babana, SOD happened to be the only protein precipitable at $>80 \%$ salt saturation. This unusually high solubility of the protein should be viewed in the context of reported differences in solubility of SODs across the mycobacterial species. For example, precipitation of $M$. tuberculosis SOD required an ammonium sulfate concentration in the range 62.5-82.5\%, whereas in the case of Mycobacterium smegmatis it was 70-85\% (Kusunose et al., 1976). As for yield, $M$. babana SOD represented as much as $1.5 \%$ of all cytosolic proteins. Identically high levels of cytosolic SOD (about $2 \%$ ) have also been reported in Nocardia (Beaman et al., 1982). However, the corresponding value for $M$. tuberculosis was only about $0.4 \%$ (Kusunose et al., 1976). The difference in cytosolic levels of SOD in various species could reflect the variability in its predisposition to behave as a secretory molecule, or merely the difference in growth conditions.

The $\mathrm{N}$-terminal sequence of $M$. babana SOD closely resembled the corresponding (deduced) sequences of $M$. leprae and $M$. tuberculosis. It also showed a structural relationship with human $\mathrm{MnSOD}$ (mitochondrial) but not with human $\mathrm{Cu}, \mathrm{ZnSOD}$ (cytosolic). Its metal cofactor was determined as $\mathrm{Fe} / \mathrm{Mn}$, which agreed with these observations. The reported cofactor is $\mathrm{Mn}$ for the $M$. leprae enzyme and $\mathrm{Fe}$ for $M$. tuberculosis. However, the deduced sequence of the $M$. tuberculosis enzyme is similar to MnSODs (Zhang et al., 1991). These discrepancies may perhaps be reconciled with a recent observation that the choice between $\mathrm{Fe}$ or $\mathrm{Mn}$ as a cofactor could largely depend on the culture conditions (Meier et al., 1982). Another important structural feature of the $M$. babana enzyme was its apparent glycosylation. Such 'posttranslational' modifications are known to distinguish native somatic proteins from their recombinant counterparts. Indeed, a good number of mycobacterial proteins have shown evidence of glycosylation (Espitia et al., 1995; Dobos et al., 1995; and other references cited within these papers). Nevertheless, it is desirable to confirm the glycosylation in SOD by more stringent methods, considering the limitations of PAS staining (Leach et al., 1980).

The most significant aspect of this study was recognition of $M$. babana SOD by T cells of not only guinea-pigs and mice primed with $M$. babana, but also of human subjects infected with $M$. leprae or exposed to environmental mycobacteria. These observations underline the relevance of 'shared' $T$ cell epitopes of mycobacterial SOD. Interestingly, in patients with tuberculoid leprosy, the patterns of $\mathrm{T}$ cell recognition of SOD and $M$. leprae extract were similar. More information on structural and antigenic aspects of $M$. babana SOD is needed to understand this phenomenon. Meanwhile, the crossreactivity between SOD of $M$. babana and $M$. leprae may be added to the list of known antigenic resemblances between the species (Lamb et al., 1990). Further, glycosylation as it may occur in the native enzyme could play an important immunological role, e.g. by modifying the process of antigen presentation to the T cells (Ishioka et al., 1992). Whatever the reason, these results indicate the possible immunopathological importance of mycobacterial SODs. Such an indication was provided earlier by Khanolkar $e t$ al. (1989), who observed that about $55 \%$ of leprosy cases had deposition of $M$. leprae SOD in the skin.

Immune recognition of the mycobacterial SOD may be seen in the larger perspective of immunodominance of those antigens which are synthesized in copious amounts under stressful situations, e.g. heat-shock proteins (Young et al., 1988). Enhanced synthesis of SOD has also been reported under conditions of stress (Amano et al., 1994) and, like heat-shock proteins, SODs from parasites bear considerable structural homologies with the host enzyme. As high as $67 \%$ homology has been noted between $M$. leprae and human MnSODs (Thangaraj et al., 1990). Nevertheless, serological differences (Kusunose $e t$ al., 1976), as well as genus and species-specific DNA sequences (Zolg \& Philippi-Schulz, 1994) of mycobacterial SODs, have been reported. Finally, in a recent report on comparative evaluation of vaccine potentials of recombinant or somatic antigens, $M$. leprae SOD was 
found to offer significant protection in the mouse footpad model of leprosy (Gelber et al., 1994). In the same experiment, the $65 \mathrm{kDa}$ heat-shock protein, a better known homologous antigen, also provided good protection.

In conclusion, our study focuses attention on the structure and antigenicity of mycobacterial SOD, visualized initially as a major $23 \mathrm{kDa}$ cytosolic protein of the vaccine candidate $M$. babana, and isolated in the native state. In the light of its immunopathological importance, it was particularly interesting to note that the enzyme was recognized by $\mathrm{T}$ cells of leprosy patients in a manner analogous to $M$. leprae. These observations put mycobacterial SOD in the same class as mycobacterial heatshock proteins, which are highly antigenic, even immunoprotective, despite bearing a prominent structural homology with the corresponding host proteins.

\section{ACKNOWLEDGEMENTS}

We are grateful to Dr V.P. Kamboj, Director, CDRI, Lucknow, for his keen interest and support, and to Dr C.M. Gupta, Director, IMT, Chandigarh, for helpful discussions. We thank Mr R.N. Khanna for photography and Messrs B. L. Srivastava and S. K. Chakrabarty for technical assistance. D. B. and J.M., respectively, are recipients of a Senior Research Fellowship and a Research Associateship of CSIR, India. $M$. leprae antigens and a selection of IMMLEP/IMMTUB mAbs used in this study were provided by the UNDP/World Bank/WHO Special Programme for Research and Training in Tropical Diseases. This paper is CDRI communication no. 5453.

\section{REFERENCES}

Amano, A., Sharma, A., Sojar, H. T., Kutramitsu, H. K. \& Genco, R. J. (1994). Effects of temperature stress on expression of fimbriae and superoxide dismutase by Porphyromonas gingivalis. Infect Immun 62, 4682-4685.

Barra, D., Schinina, M. E., Simmaco, M., Bannister, J. V., Bannister, W. H., Rotilio, G. \& Bossa, F. (1984). The primary structure of human liver manganese superoxide dismutase. J Biol Chem 259, 12595-12601.

Beaman, L. \& Beaman, B. L. (1984). The role of oxygen and its derivatives in microbial pathogenesis and host defense. Annu Rev Microbiol 38, 27-48.

Beaman, B. L., Scates, S. M., Moring, S. E., Deen, R. \& Misra, H. P. (1982). Purification and properties of a unique superoxide dismutase from Nocardia asteroides. J Biol Chem 258, 91-96.

Beauchamp, C. \& Fridovich, I. (1971). Superoxide dismutase: improved assays and an assay applicable to acrylamide gels. Anal Biochem 44, 276-287.

Boyum, A. (1968). Isolation of mononuclear cells and granulocytes from human blood. Scand J Clin Lab Invest (Suppl) 21, 77-89.

Brodie, A. F., Kalra, V. K., Lee, S. H. \& Cohen, N. S. (1979). Properties of energy transducing system in different types of membrane preparations from Mycobacterium phlei - preparation, resolution and reconstitution. Methods Enzymol 55, 175-199.

Convit, J., Sampson, C., Zuniga, N., Smith, P. G., Plata, J., Silva, J., Molina, J., Pinardi, M. E., Bloom, B. R. \& Salgado, A. (1992). Immunoprophylactic trial with combined Mycobacterium leprae/ BCG vaccine against leprosy: preliminary results. Lancet 339, $446-450$.
Cooper, J. B., Mclntyre, K., Badasso, M. O., Wood, S. P., Zhang, Y., Garbe, T. R. \& Young, D. (1995). X-ray structure analysis of the iron dependent superoxide dismutase from Mycobacterium tuberculosis at $2.0 \AA$ resolution reveals novel dimer-dimer interactions. $J \mathrm{Mol}$ Biol 246, 531-544.

Dobos, K. M., Sniderek, K., Khoo, K.-H., Brennan, P. J. \& Belisle, J. T. (1995). Evidence for glycosylation sites on the $45 \mathrm{kDa}$ glycoprotein of Mycobacterium tuberculosis. Infect Immun 63, 2846-2853.

Dunbar, B. S., Kimura, H. \& Timmons, T. M. (1990). Protein analysis using high-resolution two-dimensional polyacrylamide gel electrophoresis. Methods Enzymol 182, 441-459.

Espitia, C., Espinosa, R., Saavedra, R., Mancilla, R., Romain, F., Laqueyrerie, A. \& Moreno, C. (1995). Antigenic and structural similarities between Mycobacterium tuberculosis 50- to 55-kilodalton and $M$. bovis BCG 45- to 47-kilodalton antigens. Infect Immun 63, 580-584.

Fine, P. E. M. \& Rodriguez, L. C. (1990). Modern vaccines: mycobacterial diseases. Lancet 335, 1016-1020.

Fridovich, I. (1986). Superoxide dismutases. Adv Enzymol 58, 61-97.

Gelber, R. H., Mehra, V., Bloom, B., Murray, L. P., Siu, P., Tsang, M. \& Brennan, P. J. (1994). Vaccination with pure Mycobacterium leprae protein inhibits $M$. leprae multiplication in mouse foot pads. Infect Immun 62, 4250-4255.

Germain, R. N. (1994). MHC-dependent antigen processing and peptide presentation: providing ligands for $\mathrm{T}$ lymphocyte activation. Cell 76, 287-299.

Gupta, H. P., Singh, N. B., Mathur, I. S. \& Gupta, S. K. (1979). Mycobacterium habana, a new immunogenic strain in experimental tuberculosis. Indian J Exp Biol 17, 1190-1193.

Ishioka, G. Y., Lamont, A. G., Thomson, D., Bulbow, A., Gaeta, F. C. A., Sette, A. \& Grey, H. M. (1992). MHC interaction and T cell recognition of carbohydrate and glycopeptides. J Immunol 148, 2446-2451.

Jabusch, J. R., Forb, D. L., Kerschensteiner, D. A. \& Deutsch, H. F. (1980). Some sulfhydryl properties and primary structure of human erythrocyte superoxide dismutase. Biochemistry 19, 2310-2319.

Julius, M., Simpson, E. \& Herzenberg, L. (1973). A rapid method for isolation of functional thymus derived murine lymphocytes. Eur J Immunol 3, 645-649.

Khanolkar, S. R., Mackenzie, C. D., Lucas, S. B., Hussen, A., Girdhar, B. K., Katoch, K. \& McAdam, K. P. W. J. (1989). Identification of Mycobacterium leprae antigens in tissues of leprosy patients using monoclonal antibodies. Int J Lepr 57, 652-658.

Khanolkar-Young, S. \& Workshop Participants. (1992). Results of the third immunology of leprosy/immunology of tuberculosis antimycobacterial monoclonal antibody workshop. Infect Immun 60 , 3925-3927.

Kusunose, E., Ichihara, K., Noda, Y. \& Kusunose, M. (1976). Superoxide dismutase from Mycobacterium tuberculosis. J Biochem $\mathbf{8 0}$, 1343-1352.

Kusunose, E., Kusunose, M., Ichihara, K. \& Izumi, S. (1981). Superoxide dismutase in cell free extracts from Mycobacterium leprae grown in armadillo liver. FEMS Microbiol Lett 10, 49-52.

Laemmli, U. K. (1970). Cleavage of structural proteins during the assembly of the head of bacteriophage T4. Nature 227, 680-685.

Lamb, F. I., Singh, N. B. \& Colston, M. J. (1990). The specific 18 kilodalton antigen of Mycobacterium leprae is present in Mycobacterium babana and functions as a heat-shock protein. I Immunol 144, 1922-1925. 
Leach, B. S., Collawn, J. F., Jr \& Fish, W. W. (1980). Behavior of glycoproteins with empirical molecular weight estimation methods. I. In sodium dodecyl sulfate. Biochemistry 19, 5734-5741.

Markwell, M. A. K., Haas, S. M., Bieber, L. L. \& Tolbert, N. E. (1978). A modification of the Lowry procedure to simplify protein determination in membrane and lipoprotein samples. Anal Biochem 87, 206-210.

Matsudaira, P. (1987). Sequence from picomole quantities of protein electroblotted onto polyvinylidene difluoride membranes. $J$ Biol Chem 262, 10035-10038.

Meier, B., Barra, D., Bossa, F., Calabrese, L. \& Rotilio, G. (1982). Synthesis of either $\mathrm{Fe}$ or $\mathrm{Mn}$ superoxide dismutase with an apparently identical protein moiety by an anaerobic bacterium dependent on the metal supplied. J Biol Chem 257, 13977-13980.

Radi, R., Beckman, J. S., Bush, K. M. \& Freeman, B. A. (1991). Peroxynitrite induced membrane lipid peroxidation: the cytotoxic potential of superoxide and nitric oxide. Arch Biochem Biopbys 288, 481-487.

Ridley, D. S. \& Jopling, W. H. (1966). Classification of leprosy according to immunity: a five group system. Int J Lepr 34, 255-273.

Scopes, R. K. (1987). Separation by precipitation: salting out at high salt concentration. In Protein Purification: Principles and Practice, pp. 43-52. New York: Springer-Verlag.

Singh, N. B., Lowe, A. C. R. E., Rees, R. J. W. \& Colston, M. J. (1989). Vaccination of mice against Mycobacterium leprae infection. Infect Immun 57, 653-655.

Singh, N. B., Srivastava, A., Gupta, H. P., Ashok \& Srivastava, S. (1992). Induction of lepromin positivity in monkeys by a candidate antileprosy vaccine: Mycobacterium babana. Int J Lepr 59, 317-320.

Sinha, S., Sreevatsa, Gupta, S. K. \& Sengupta, U. (1987). Comparative study of immunizing and delayed hypersensitivity eliciting antigens of Mycobacterium leprae, $M$. tuberculosis, $M$. vaccae, and $M$. bovis BCG. Int J Lepr 55, 42-53.

Spiegelhalder, C., Gerstenecker, B., Kersten, A., Schiltz, E. \& Kist, M. (1993). Purification of Helicobacter pylori superoxide dismutase and cloning and sequencing of the gene. Infect Immun 61, 5315-5325.

Takao, M., Yasui, A. \& Oikawa, A. (1991). Unique characteristics of superoxide dismutase of a strictly anaerobic archaebacterium Methanobacterium thermoautotrophicum. J Biol Chem 266, 14151-14154.

Thangaraj, H. S., Lamb, F. I., Davis, E. O. \& Colston, M. J. (1989).
Nucleotide and deduced amino acid sequence of Mycobacterium leprae manganese superoxide dismutase. Nucleic Acids Res 17, 8378.

Thangaraj, H. S., Lamb، F. I., Davis, E. O., Jenner, P. J., Jeyakumar, L. H. \& Colston, M. J. (1990). Identification, sequencing, and expression of Mycobacterium leprae superoxide dismutase, a major antigen. Infect Immun 58, 1937-1942.

Towbin, H., Staehelin, T. \& Gordon, J. (1979). Electrophoretic transfer of proteins from polyacrylamide gels to nitrocellulose sheets: procedure and some applications. Proc Natl Acad Sci USA 76, 4350-4354.

Weiss, R. (1992). On the track of 'killer' TB. Science 235, 148-150.

Wheeler, P. R. \& Gregory, D. (1980). Superoxide dismutase, peroxidatic activity and catalase in Mycobacterium leprae purified from armadillo liver. J Gen Microbiol 121, 457-464.

WHO (1988). Sixth Report of the WHO Expert Committee on Leprosy. Technical Report Series no. 768.

Wray, W., Boulikas, T., Wray, V. P. \& Hancock, R. (1981). Silver staining of proteins in polyacrylamide gels. Anal Biochem 118, 197-203.

Young, D. B. \& Cole, S. T. (1993). Leprosy, tuberculosis, and new genetics. J Bacteriol 175, 1-6.

Young, D. B., Fohn, M. J., Khanolkar, S. R. \& Buchanan, T. M. (1985). Monoclonal antibodies to a $28 \mathrm{kD}$ protein antigen of Mycobacterium leprae. Clin Exp Immunol 60, 546-562.

Young, D., Lathigra, R., Hendrix, R., Sweetser, D. \& Young, R. A. (1988). Stress proteins are immune targets in leprosy and tuberculosis Proc Natl Acad Sci US A 85, 4267-4270.

Young, D., Hermans, P. M. W., Kaufmann, S.H. E. \& Thole, J. E. R. (1992). Mycobacterial protein antigens: a compilation. Mol Microbiol 6, 153-163.

Zhang, Y., Lathigra, R., Garbe, T., Catty, D. \& Young, D. (1991). Genetic analysis of superoxide dismutase, the 23 kilodalton antigen of Mycobacterium tuberculosis. Mol Microbiol 5, 381-391.

Zolg, J. W. \& Philippi-Schulz, S. (1994). The superoxide dismutase gene. A target for detection and identification of mycobacteria by PCR. J Clin Microbiol 32, 2801-2812.

Received 21 August 1995; revised 3 January 1996; accepted 16 January 1996. 